\title{
The Role of lncRNAs in the Pathobiology and Clinical Behavior of Multiple Myeloma
}

\author{
Arantxa Carrasco-León ${ }^{1,2} \mathbb{D}$, Ane Amundarain ${ }^{1,2} \mathbb{D}$, Nahia Gómez-Echarte ${ }^{1,2}$, Felipe Prósper ${ }^{1,2,3, *(\mathbb{D})}$ and \\ Xabier Agirre 1,2,*(D)
}

1 Área de Hemato-Oncología, Centro de Investigación Médica Aplicada (CIMA), IDISNA, Universidad de Navarra, Avenida Pío XII-55, 31008 Pamplona, Spain; acleon@alumni.unav.es (A.C.-L.); aamundarain.1@alumni.unav.es (A.A.); ngomez.9@alumni.unav.es (N.G.-E.)

2 Centro de Investigación Biomédica en Red de Cáncer (CIBERONC), 31008 Pamplona, Spain

3 Departamento de Hematología, Clínica Universidad de Navarra, Universidad de Navarra, Avenida Pío XII-36, 31008 Pamplona, Spain

* Correspondence: fprosper@unav.es (F.P.); xaguirre@unav.es (X.A.); Tel.: +34-948-255400 (ext. 5807) (F.P.); +34-948-194700 (ext. 1002) (X.A.)

Citation: Carrasco-León, A.; Amundarain, A.; Gómez-Echarte, N.; Prósper, F.; Agirre, X. The Role of lncRNAs in the Pathobiology and Clinical Behavior of Multiple Myeloma. Cancers 2021, 13, 1976. https://doi.org/10.3390/cancers13081976

Academic Editors

Domenica Ronchetti and Niccolò Bolli

Received: 26 March 2021

Accepted: 16 April 2021

Published: 20 April 2021

Publisher's Note: MDPI stays neutral with regard to jurisdictional claims in published maps and institutional affiliations.

Simple Summary: Multiple myeloma (MM), the second most common hematological neoplasm, is still considered an incurable disease. Long non-coding RNAs (lncRNAs), genes that do not encode proteins, participate in numerous biological processes, but their deregulation, like that of coding genes, can contribute to carcinogenesis. Increasing evidence points to the relevant role of lncRNAs in the development of human tumors, such that they emerge as attractive biomarkers and therapeutic targets for cancer treatment, including MM. Here we review the oncogenic or tumor-suppressor functions of lncRNAs in MM and provide an overview of novel therapeutic approaches based on lncRNAs that will help to improve the management of these patients.

Abstract: $\mathrm{MM}$ is a hematological neoplasm that is still considered an incurable disease. Besides established genetic alterations, recent studies have shown that MM pathogenesis is also characterized by epigenetic aberrations, such as the gain of de novo active chromatin marks in promoter and enhancer regions and extensive DNA hypomethylation of intergenic regions, highlighting the relevance of these non-coding genomic regions. A recent study described how long non-coding RNAs (lncRNAs) correspond to $82 \%$ of the MM transcriptome and an increasing number of studies have demonstrated the importance of deregulation of lncRNAs in MM. In this review we focus on the deregulated lncRNAs in MM, including their biological or functional mechanisms, their role as biomarkers to improve the prognosis and monitoring of MM patients, and their participation in drug resistance. Furthermore, we also discuss the evidence supporting the role of lncRNAs as therapeutic targets through different novel RNA-based strategies.

Keywords: lncRNAs; multiple myeloma; RNA-based therapy

\section{Introduction}

Multiple myeloma (MM) is a hematological neoplasm characterized by the uncontrolled aberrant clonal proliferation of plasma cells (PCs) in the bone marrow [1]. This disease is the second most common hematological malignancy, after non-Hodgkin lymphoma [2,3], affecting elderly patients with a median age of 65 years [4]. Despite the latest advances in treatment strategies, which have significantly increased patient survival, MM is still considered an incurable disease, with a median overall survival of 7 years.

$\mathrm{MM}$ is a very heterogeneous disease, which is reflected in the inter-individual differential diagnosis and survival of patients. Different studies have associated this variability with a wide range of genetic and epigenetic alterations present in MM patients [5,6], including distinct molecularly defined subtypes with different features [7]. Regarding the 
genetic variability, MM is divided into hyperdiploid (HRD) and non-HRD subtypes [7]. HRD MM is characterized by the trisomy of chromosomes 3, 5, 7, 9, 11, 15, 19 and 21 [6], whereas non-HRD MM is characterized by translocations of the immunoglobulin (Ig) alleles. The majority of these translocations affect chromosome 14, where the Ig $\mathrm{H}$-chain is located [6,7]. However, Ig translocations can also affect the kappa and lambda light chains, the co-occurrence of which is common with HRD MM. Besides, some of these lightchain translocations are associated with a poor outcome for MM patients, as is the case for IgL-MYC translocations [8]. Some of the common heavy-chain translocations are also considered as high-risk prognostic factors, such as $\mathrm{t}(4 ; 14)$ and $\mathrm{t}(14 ; 16)$, which affect MMSET and $M A F$ genes, respectively [6,7,9]. Epigenetic aberrations of the DNA methylation and histone modifications are also thought to play an important role in MM pathogenesis. The study of global DNA methylation of MM has led to the identification of a highly heterogeneous DNA methylation pattern, which results in extensive DNA hypomethylation of intergenic regions and DNA hypermethylation associated with intronic and enhancer regions [2,5]. In addition, the study of histone modifications in MM has revealed a de novo gain of active chromatin marks preferentially located in regulatory elements, such as enhancer and promoter regions, which arise from heterochromatic regions in normal $B$ cells [10-12]. These results suggest the possibility that these epigenetically regulated non-coding genomic regions could lead to the transcription of non-coding RNA genes (ncRNAs) and, in particular, to the expression of long non-coding RNAs (lncRNAs), which may play a relevant role in the pathobiology and clinical outcome of MM [13]. Nowadays, studies about the role of certain lncRNAs in MM are emerging. However, more comprehensive analyses are required to better understand their function in this disease. In this review, we summarize the current knowledge regarding the role of lncRNAs in the development and outcome of MM and discuss the possibility of lncRNAs as targets for the development of novel RNA-based therapeutic strategies for MM patients.

\section{Features of lncRNAs}

Traditionally, cellular functions of DNA and proteins have overshadowed the roles of RNAs. In recent years, the development of high-throughput techniques, such as RNA sequencing (RNA-seq), has brought great advances in the understanding of the cell transcriptome. So far, it is known that, although only $1-2 \%$ of the human genome is translated into proteins, around $70-90 \%$ of it is transcribed into RNA, resulting in a huge amount of ncRNAs [14]. Among these ncRNA genes, lncRNAs are defined as those non-coding transcripts longer than $200 \mathrm{nt}$ that do not encode proteins, with open reading frames (ORFs) smaller than 100 amino acids, and with a lack of or low coding potential. However, the latest RNA-seq studies have shown that some lncRNAs contain cryptic ORFs, which could encode for small ORFs or non-conserved peptides [15-17].

The characteristics of IncRNAs may differ from each other and they can be capped at the $5^{\prime}$ end, spliced and/or polyadenylated (poly(A)+). Remarkably, transcripts with the poly(A)+ tail have higher stability than those with poor or no polyadenylation. On the other hand, there are lncRNAs that can present both polyadenylated and non-polyadenylated isoforms, such as MALAT1 (metastasis associated lung adenocarcinoma transcript 1) or NEAT1 (nuclear paraspeckle assembly transcript 1) [18,19]. Although the size of lncRNAs varies between $200 \mathrm{nt}$ and more than $1 \mathrm{MB}$ (known as macro lncRNAs), $42 \%$ of $\operatorname{lncRNAs}$ only present two exons $[19,20]$. In contrast to mRNAs, which are located at the cytosol, IncRNAs can be located either in the nucleus or in the cytoplasm, where they can exert various functions. Thus, regarding the location where lncRNAs act and their transcription site, they are capable of acting as cis and/or trans transcripts [15,21]. Cis lncRNAs are known to influence the expression and/or chromatin states of their neighboring genes, while trans lncRNAs act over distal genes [22-24]. Interestingly, lncRNAs are cell- and tissue-specific, and they may affect different biological processes, such as chromosome conformation, imprinting of genomic loci, or gene and protein regulation $[15,25]$. lncRNAs have the ability to regulate at DNA, RNA and protein levels, and their functions can 
be divided into four different groups depending on their molecular mechanisms [18,26]: (1) signal lncRNAs are regulatory molecules that can trigger the transcription of other genes by their presence. They can infer chromatin states, affect gene imprinting or mark certain spaces, times or stages for gene regulation, such as Air or PANDA (p21-associated ncRNA DNA damage activated) [26,27]. (2) Decoy lncRNAs are transcripts that bind to targets and prevent them from binding to their own targets, thus leading to the alteration of post-transcriptional control. This type of lncRNA can act as an miRNA sponge, binding to miRNAs thanks to their complementary sequence (Figure 1) [26]; PTENP1 (phosphatase and tensin homolog pseudogene 1), for example, leads to tumor suppressor activity due to the decoy of different miRNAs [28-30]. (3) Guide lncRNAs can regulate gene expression through the recruitment and re-localization of ribonucleoprotein complexes at specific chromatin loci, such as MEG3 (maternally expressed 3), which guides the EZH2 subunit to TGF $\beta$-regulated genes (Table 1) [18,31,32]. (4) Scaffold lncRNAs can act as central platforms upon the assembly of different ribonucleoprotein complexes, affecting their molecular components (Figure 1) [32]; for instance, HOTAIR (HOX transcript antisense intergenic RNA) adopts a four-module secondary structure for the interaction with polycomb repressive complex 2 (PRC2) (Table 1), promoting gene repression [18,26]. 


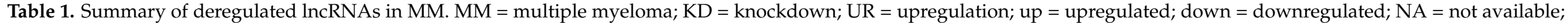
$\mathrm{PFS}$ = progression-free survival; OS = overall survival.

\begin{tabular}{|c|c|c|c|c|c|c|c|c|c|}
\hline Gene & Location & Gene Type & $\begin{array}{c}\text { Expression in } \\
\text { MM }\end{array}$ & $\begin{array}{c}\text { Molecular } \\
\text { Mechanism }\end{array}$ & $\begin{array}{c}\text { Molecular } \\
\text { Interaction in MM }\end{array}$ & $\begin{array}{l}\text { Biological Effect } \\
\text { after lncRNA KD }\end{array}$ & $\begin{array}{l}\text { Biological } \\
\text { Effect after } \\
\text { lncRNA UR }\end{array}$ & Prognosis in MM & References \\
\hline ANRIL & $9 \mathrm{p} 21.3$ & Antisense & Up & Decoy & $\begin{array}{l}\text { Binds to } m i R-34 a \\
m i R-125 a, m i R-186 \\
\text { and } m i R- \\
411-3 p\end{array}$ & $\begin{array}{l}\text { Decreases cellular } \\
\text { proliferation and } \\
\text { increases apoptosis }\end{array}$ & NA & $\begin{array}{l}\text { High expression } \\
\text { levels associated with } \\
\text { worse PFS and OS }\end{array}$ & {$[33,34]$} \\
\hline BM742401 & $18 q 11.2$ & LincRNA & Down & NA & NA & NA & $\begin{array}{l}\text { Decreases cell } \\
\text { migration }\end{array}$ & $\begin{array}{l}\text { Methylated lncRNA } \\
\text { associated with worse } \\
\text { OS }\end{array}$ & [35] \\
\hline Circ_0000190 & $1 q 42.12$ & $\begin{array}{l}\text { Circular } \\
\text { lncRNA }\end{array}$ & Down & NA & NA & NA & NA & $\begin{array}{l}\text { High expression } \\
\text { levels associated with } \\
\text { better PFS and OS }\end{array}$ & [36-38] \\
\hline CRNDE & 16q12.2 & LincRNA & Up & Decoy & Binds to $m i R-451$ & $\begin{array}{c}\text { Decreases cellular } \\
\text { proliferation, } \\
\text { increases apoptosis } \\
\text { and triggers cell cycle } \\
\text { arrest }\end{array}$ & NA & $\begin{array}{c}\text { High expression } \\
\text { levels associated with } \\
\text { worse OS }\end{array}$ & {$[39,40]$} \\
\hline ENSG00000249988 & 4p15.33 & LincRNA & Up & NA & NA & NA & NA & $\begin{array}{c}\text { High expression } \\
\text { levels associated with } \\
\text { worse PFS andbetter } \\
\text { OS }\end{array}$ & [13] \\
\hline ENSG00000254343 & $8 \mathrm{q} 24.12$ & LincRNA & Up & NA & NA & NA & NA & $\begin{array}{c}\text { High expression } \\
\text { levels associated with } \\
\text { worse PFS }\end{array}$ & [13] \\
\hline
\end{tabular}


Table 1. Cont.

\begin{tabular}{|c|c|c|c|c|c|c|c|c|c|}
\hline Gene & Location & Gene Type & $\begin{array}{l}\text { Expression in } \\
\text { MM }\end{array}$ & $\begin{array}{l}\text { Molecular } \\
\text { Mechanism }\end{array}$ & $\begin{array}{c}\text { Molecular } \\
\text { Interaction in MM }\end{array}$ & $\begin{array}{l}\text { Biological Effect } \\
\text { after lncRNA KD }\end{array}$ & $\begin{array}{l}\text { Biological } \\
\text { Effect after } \\
\text { lncRNA UR }\end{array}$ & Prognosis in MM & References \\
\hline FEZF1-AS1 & 7q31.32 & Antisense & Up & Decoy & $\begin{array}{l}\text { Binds to } m i R-610 \\
\text { and regulates AKT3 }\end{array}$ & $\begin{array}{c}\text { Decreases cellular } \\
\text { proliferation, } \\
\text { increases apoptosis } \\
\text { and triggers cell cycle } \\
\text { arrest }\end{array}$ & NA & NA & [42] \\
\hline GAS5 & $1 \mathrm{q} 25.1$ & $\begin{array}{l}\text { Processed } \\
\text { transcript }\end{array}$ & Down & NA & NA & NA & $\begin{array}{c}\text { Decreases } \\
\text { cellular } \\
\text { proliferation }\end{array}$ & NA & [43] \\
\hline H19 & 11 p15.5 & $\begin{array}{l}\text { Processed } \\
\text { transcript }\end{array}$ & Up & Decoy & $\begin{array}{l}\text { Binds to } m i R-152-3 p \\
\text { and } m i R-29 b-3 p\end{array}$ & $\begin{array}{c}\text { Decreases cellular } \\
\text { proliferation, } \\
\text { increases apoptosis } \\
\text { and triggers cell cycle } \\
\text { arrest }\end{array}$ & NA & $\begin{array}{c}\text { High expression } \\
\text { levels associated with } \\
\text { worse PFS }\end{array}$ & [44-46] \\
\hline HOTAIR & 12q13.31 & Antisense & $\mathrm{Up}$ & NA & $\begin{array}{l}\text { Activates NF-кB } \\
\text { pathway }\end{array}$ & $\begin{array}{l}\text { Decreases cellular } \\
\text { proliferation, triggers } \\
\text { cell cycle arrest and } \\
\text { decreases } \\
\text { chemoresistance to } \\
\text { dexamethasone }\end{array}$ & NA & NA & {$[21,47-49]$} \\
\hline HOXB-AS1 & $17 q 21.32$ & Antisense & Up & Scaffold & $\begin{array}{c}\text { Scaffold for } \\
\text { ELAVL1. Interacts } \\
\text { with } \\
\text { FUT4-mediated } \\
\text { Wnt/ } \beta \text {-catenin } \\
\text { pathway }\end{array}$ & $\begin{array}{l}\text { Decreases cellular } \\
\text { proliferation and } \\
\text { increases apoptosis }\end{array}$ & NA & NA & {$[50]$} \\
\hline IRAIN & $15 q 26.3$ & Antisense & Down & Decoy & $\begin{array}{l}\text { Binds to } m i R-125 b \\
\text { and regulates IGF-1 } \\
\text { signaling }\end{array}$ & NA & $\begin{array}{l}\text { Increases } \\
\text { apoptosis }\end{array}$ & NA & {$[51,52]$} \\
\hline
\end{tabular}


Table 1. Cont.

\begin{tabular}{|c|c|c|c|c|c|c|c|c|c|}
\hline Gene & Location & Gene Type & $\begin{array}{c}\text { Expression in } \\
\text { MM }\end{array}$ & $\begin{array}{l}\text { Molecular } \\
\text { Mechanism }\end{array}$ & $\begin{array}{c}\text { Molecular } \\
\text { Interaction in MM }\end{array}$ & $\begin{array}{l}\text { Biological Effect } \\
\text { after lncRNA KD }\end{array}$ & $\begin{array}{l}\text { Biological } \\
\text { Effect after } \\
\text { lncRNA UR }\end{array}$ & Prognosis in MM & References \\
\hline LINC00152 & $2 \mathrm{p} 11.2$ & LincRNA & Up & Decoy & Binds to $m i R-497$ & $\begin{array}{c}\text { Decreases cellular } \\
\text { proliferation, } \\
\text { increases apoptosis } \\
\text { and triggers cell cycle } \\
\text { arrest. Decreases } \\
\text { tumorigenesis in vivo }\end{array}$ & NA & $\begin{array}{c}\text { High expression } \\
\text { levels associated with } \\
\text { worse OS }\end{array}$ & [53] \\
\hline LINC00461 & $5 q 14.3$ & LincRNA & Up & NA & NA & $\begin{array}{l}\text { Decreases cellular } \\
\text { proliferation and } \\
\text { increases apoptosis }\end{array}$ & NA & $\begin{array}{c}\text { High expression } \\
\text { levels associated with } \\
\text { worse OS }\end{array}$ & [54-56] \\
\hline LINC00515 & $21 q 21.3$ & LincRNA & $\mathrm{Up}$ & Decoy & Binds to $m i R-140-5 p$ & Increases apoptosis & NA & NA & [57] \\
\hline LINC00665 & $19 q 13.12$ & LincRNA & Up & Decoy & Binds to $m i R-214-3 p$ & $\begin{array}{l}\text { Decreases cellular } \\
\text { proliferation and } \\
\text { increases apoptosis }\end{array}$ & NA & NA & {$[58]$} \\
\hline LINC01234 & $12 \mathrm{q} 24.13$ & LincRNA & Up & Decoy & Binds to $m i R-124-3 p$ & $\begin{array}{l}\text { Decreases cellular } \\
\text { proliferation and } \\
\text { increases apoptosis. } \\
\text { Decreases cell } \\
\text { proliferation and } \\
\text { tumor growth in vivo }\end{array}$ & NA & $\begin{array}{c}\text { High expression } \\
\text { levels associated with } \\
\text { worse OS }\end{array}$ & [59] \\
\hline $\operatorname{lnc}-A N G P T L 1-3$ & $1 \mathrm{q} 25.2$ & Antisense & Up & Decoy & Binds to $m i R-30 a-3 p$ & $\begin{array}{l}\text { Increases the } \\
\text { sensitivity to } \\
\text { bortezomib }\end{array}$ & NA & $\begin{array}{c}\text { High expression } \\
\text { levels associated with } \\
\text { worse OS }\end{array}$ & {$[60]$} \\
\hline $\operatorname{lnc}-\mathrm{TCF} 7$ & $5 q 31.1$ & NA & Up & NA & NA & NA & NA & $\begin{array}{l}\text { High expression } \\
\text { levels associated with } \\
\text { worse PFS and OS }\end{array}$ & [61] \\
\hline LUCAT1 & $5 q 14.3$ & LincRNA & Up & NA & $\begin{array}{c}\text { Activates the TGF- } \beta \\
\text { signaling pathway }\end{array}$ & $\begin{array}{c}\text { Decreases cellular } \\
\text { proliferation, } \\
\text { increases apoptosis } \\
\text { and triggers cell cycle } \\
\text { arrest }\end{array}$ & NA & $\begin{array}{l}\text { High expression } \\
\text { levels associated with } \\
\text { shorter five-year } \\
\text { survival }\end{array}$ & {$[62]$} \\
\hline
\end{tabular}


Table 1. Cont.

\begin{tabular}{|c|c|c|c|c|c|c|c|c|c|}
\hline Gene & Location & Gene Type & $\begin{array}{c}\text { Expression in } \\
\text { MM }\end{array}$ & $\begin{array}{l}\text { Molecular } \\
\text { Mechanism }\end{array}$ & $\begin{array}{c}\text { Molecular } \\
\text { Interaction in MM }\end{array}$ & $\begin{array}{l}\text { Biological Effect } \\
\text { after lncRNA KD }\end{array}$ & $\begin{array}{c}\text { Biological } \\
\text { Effect after } \\
\text { lncRNA UR }\end{array}$ & Prognosis in $\mathrm{MM}$ & References \\
\hline MALAT1 & 11q13.1 & LincRNA & Up & $\begin{array}{l}\text { Decoy and } \\
\text { Scaffold }\end{array}$ & $\begin{array}{c}\text { Binds to } \\
\text { miR-1271-5p } \\
\text { miR-181a-5p and } \\
\text { miR-509- } \\
\text { 5p. Scaffold for } \\
\text { PARP1 }\end{array}$ & $\begin{array}{l}\text { Decreases cellular } \\
\text { proliferation and } \\
\text { increases apoptosis }\end{array}$ & NA & $\begin{array}{c}\text { High expression } \\
\text { levels associated with } \\
\text { worse PFS and OS }\end{array}$ & {$[63-70]$} \\
\hline MEG3 & $14 q 32.2$ & LincRNA & Down & Decoy & Binds to $m i R-181 a$ & NA & $\begin{array}{l}\text { Decreases } \\
\quad \text { cellular } \\
\text { proliferation } \\
\text { and increases } \\
\text { apoptosis }\end{array}$ & $\begin{array}{c}\text { High expression } \\
\text { levels associated with } \\
\text { better PFS and OS }\end{array}$ & [71-74] \\
\hline MIAT & $22 q 12.1$ & LincRNA & Up & Decoy & Binds to $m i R-29 b$ & $\begin{array}{l}\text { Sensitizes MM cells to } \\
\text { bortezomib }\end{array}$ & NA & $\begin{array}{l}\text { High expression } \\
\text { levels associated with } \\
\text { worse PFS and OS }\end{array}$ & {$[75,76]$} \\
\hline NEAT1 & 11q13.1 & LincRNA & Up & Decoy & $\begin{array}{l}\text { Binds to } m i R-214 \\
\text { and } m i R-125 a\end{array}$ & $\begin{array}{l}\text { Decreases cellular } \\
\text { proliferation }\end{array}$ & NA & $\begin{array}{c}\text { High expression } \\
\text { levels associated with } \\
\text { worse PFS and OS }\end{array}$ & {$[77-80]$} \\
\hline OIP5-AS1 & $15 q 15.1$ & $\begin{array}{l}\text { Processed } \\
\text { transcript }\end{array}$ & Down & Decoy & $\begin{array}{l}\text { Binds to } m i R-410 \\
\text { and } m i R-27 a-3 p\end{array}$ & NA & $\begin{array}{l}\text { Decreases } \\
\quad \text { cellular } \\
\text { proliferation } \\
\text { and increases } \\
\text { apoptosis }\end{array}$ & NA & {$[81,82]$} \\
\hline PCAT-1 & $8 q 24.21$ & LincRNA & Up & Decoy & Binds to $m i R-129$ & $\begin{array}{l}\text { Increases apoptosis } \\
\text { and sensitizes MM } \\
\text { cells to bortezomib }\end{array}$ & NA & NA & {$[83,84]$} \\
\hline PDIAЗР & $1 \mathrm{q} 21.1$ & Pseudogene & Up & NA & NA & $\begin{array}{l}\text { Decreases cellular } \\
\text { proliferation. } \\
\text { Increases the } \\
\text { sensitivity to } \\
\text { bortezomib }\end{array}$ & NA & $\begin{array}{c}\text { High expression } \\
\text { levels associated with } \\
\text { worse OS }\end{array}$ & [85] \\
\hline
\end{tabular}


Table 1. Cont.

\begin{tabular}{|c|c|c|c|c|c|c|c|c|c|}
\hline Gene & Location & Gene Type & $\begin{array}{c}\text { Expression in } \\
\mathrm{MM}\end{array}$ & $\begin{array}{l}\text { Molecular } \\
\text { Mechanism }\end{array}$ & $\begin{array}{c}\text { Molecular } \\
\text { Interaction in MM }\end{array}$ & $\begin{array}{l}\text { Biological Effect } \\
\text { after lncRNA KD }\end{array}$ & $\begin{array}{l}\text { Biological } \\
\text { Effect after } \\
\text { lncRNA UR }\end{array}$ & Prognosis in $\mathrm{MM}$ & References \\
\hline PDLIM1P4 & $3 q 12.1$ & Pseudogene & Up & NA & NA & NA & NA & $\begin{array}{c}\text { High expression } \\
\text { levels associated with } \\
\text { worse PFS and OS }\end{array}$ & [13] \\
\hline$P R A L$ & $17 \mathrm{p} 13.1$ & NA & Down & Decoy & Binds to $m i R-210$ & NA & $\begin{array}{l}\text { Decreases } \\
\text { cellular } \\
\text { proliferation } \\
\text { and increases } \\
\text { apoptosis. } \\
\text { Increases the } \\
\text { anti-tumor } \\
\text { effect of } \\
\text { bortezomib }\end{array}$ & $\begin{array}{c}\text { High expression } \\
\text { levels associated with } \\
\text { better PFS and OS }\end{array}$ & {$[86,87]$} \\
\hline PVT1 & $8 \mathrm{q} 24.21$ & $\begin{array}{l}\text { Processed } \\
\text { transcript }\end{array}$ & Up & Decoy & $\begin{array}{l}\text { Binds to miR-203a. } \\
\text { It is inhibited by } \\
\text { BRD4 }\end{array}$ & $\begin{array}{l}\text { Decreases cellular } \\
\text { proliferation and } \\
\text { increases apoptosis }\end{array}$ & NA & NA & {$[88,89]$} \\
\hline SNHG16 & $17 q 25.1$ & $\begin{array}{l}\text { Processed } \\
\text { transcript }\end{array}$ & Up & Decoy & Binds to $m i R-342-3 p$ & $\begin{array}{c}\text { Decreases cellular } \\
\text { proliferation, } \\
\text { increases apoptosis } \\
\text { and triggers cell cycle } \\
\text { arrest }\end{array}$ & NA & NA & [90] \\
\hline SOX $2 O T$ & $3 q 26.3$ & $\begin{array}{c}\text { Sense } \\
\text { overlapping }\end{array}$ & Up & Decoy & Binds to $m i R-144-3 p$ & $\begin{array}{l}\text { Decreases cellular } \\
\text { proliferation, } \\
\text { increases apoptosis } \\
\text { and triggers cell cycle } \\
\text { arrest. Decreases } \\
\text { tumor growth in vivo }\end{array}$ & NA & NA & [91] \\
\hline
\end{tabular}


Table 1. Cont.

\begin{tabular}{|c|c|c|c|c|c|c|c|c|c|}
\hline Gene & Location & Gene Type & $\begin{array}{c}\text { Expression in } \\
\text { MM }\end{array}$ & $\begin{array}{c}\text { Molecular } \\
\text { Mechanism }\end{array}$ & $\begin{array}{c}\text { Molecular } \\
\text { Interaction in MM }\end{array}$ & $\begin{array}{l}\text { Biological Effect } \\
\text { after lncRNA KD }\end{array}$ & $\begin{array}{c}\text { Biological } \\
\text { Effect after } \\
\text { lncRNA UR }\end{array}$ & Prognosis in $\mathrm{MM}$ & References \\
\hline ST3GAL6-AS1 & $3 q 12.1$ & Antisense & Up & NA & NA & $\begin{array}{c}\text { Decreases cellular } \\
\text { proliferation, } \\
\text { increases apoptosis } \\
\text { and triggers cell cycle } \\
\text { arrest }\end{array}$ & NA & $\begin{array}{c}\text { High expression } \\
\text { levels associated with } \\
\text { worse PFS }\end{array}$ & {$[92,93]$} \\
\hline TUG1 & $22 q 12.2$ & Antisense & Up & Decoy & $\begin{array}{l}\text { Binds to } m i R-29 b-3 p \\
\text { and targets HDAC4 }\end{array}$ & $\begin{array}{l}\text { Decreases cellular } \\
\text { proliferation and } \\
\text { increases apoptosis }\end{array}$ & NA & NA & {$[43,94]$} \\
\hline UCA1 & 19p13.12 & $\begin{array}{l}\text { Processed } \\
\text { transcript }\end{array}$ & Up & Decoy & $\begin{array}{c}\text { Binds to } \\
m i R-1271-5 p \text { and } \\
m i R-331-3 p\end{array}$ & $\begin{array}{l}\text { Decreases cellular } \\
\text { proliferation and } \\
\text { increases apoptosis }\end{array}$ & NA & $\begin{array}{c}\text { High expression } \\
\text { levels associated with } \\
\text { worse OS }\end{array}$ & {$[95,96]$} \\
\hline XLOC_013703 & 20p11.21 & NA & Down & NA & $\begin{array}{l}\text { Involved in NF-кB } \\
\text { signaling activation }\end{array}$ & NA & $\begin{array}{l}\text { Decreases } \\
\text { cellular } \\
\text { proliferation } \\
\text { and increases } \\
\text { apoptosis }\end{array}$ & NA & [97] \\
\hline
\end{tabular}




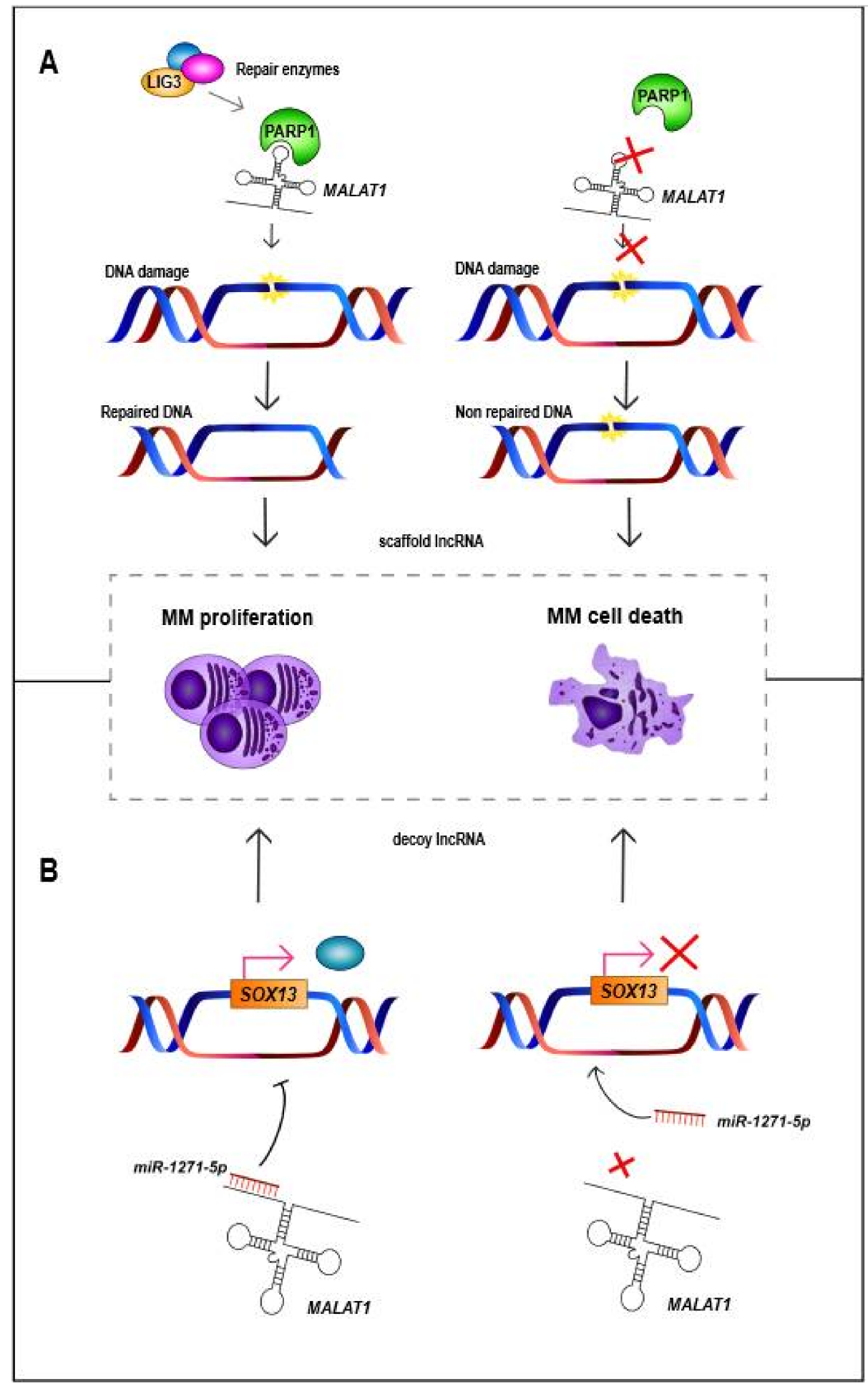

Figure 1. Mechanisms by which MALAT1 acts in MM cells. (A) MALAT1 acts as scaffold lncRNA, binding to PARP1 protein, which binds to a complex of DNA-repair enzymes consisting of LIG3 among others. Then, the protein-MALAT1 complex repairs the damaged DNA, triggering the proliferation of MM cells. However, when binding of MALAT1 and PARP1 does not occur, damaged DNA is not repaired, triggering MM cell death [70]. (B) MALAT1 can also act as a miRNA sponge (decoy), binding to different miRNAs such as miR-1271-5p, a tumor-suppressor miRNA that negatively regulates SOX13. Binding of MALAT1 and miR-1271-5p triggers overexpression of SOX13 and proliferation of MM cells, whereas knockdown of MALAT1 releases miR-1271-5p, which binds and prevents translation of SOX13. MM = multiple myeloma. 


\section{Role of IncRNAs in the Pathobiology of MM}

Diverse studies have pointed to the importance of lncRNAs in different biological processes, such as immune response, cell differentiation, gene expression modulation and chromatin reorganization $[98,99]$. Intriguingly, their deregulation also contributes to the development of carcinogenesis, metastasis and even anti-cancer treatment resistance [63]. The deregulation of the expression of lncRNAs can thus impact on relevant pathways involved in the pathogenesis and/or progression of certain human tumors, including MM $[43,71]$. We have recently demonstrated that $82 \%$ of the transcriptome, including coding genes and all types of polyA+ and non-polyA lncRNAs, in plasma cells from MM correspond to lncRNAs, compared to $18 \%$ of coding genes [13].

Some deregulated IncRNAs in MM also appear deregulated in the same way in other types of human cancer: for example, HOTAIR is upregulated in hepatocellular carcinoma (HCC), PDIA3P (protein disulfide isomerase family A member 3 pseudogene 1) in lung cancer, and LINC00461 in both HCC and lung cancer, all three of them being also upregulated in MM [47-49,54-56,100]. PRAL (P53 regulation associated lncRNA) is downregulated in HCC, lung cancer and MM, and GAS5 (growth arrest specific 5) in breast, prostate, renal cancer and MM [43,86,87,101,102]. However, there are lncRNAs that are deregulated in $\mathrm{MM}$ while they show the opposite direction of expression in other neoplasms. For instance, MALAT1 is upregulated in MM, lung cancer, gallbladder cancer, colorectal carcinoma and HCC, whilst this lncRNA is downregulated in colorectal and glioma cancer $[64,103,104]$. NEAT1 is also upregulated in MM, lung cancer and HCC, but is downregulated in acute promyelocytic leukemia [105]. Finally, Circ_0000190 is downregulated in $\mathrm{MM}$ and gastric cancer, whereas it displays overexpression in lung cancer [36-38]. These results highlight the cell- and tissue- specificity of lncRNAs, showing that their deregulation - and thus, their potential function - needs to be addressed in each tumor. For example, MALAT1 (one of the most widely studied lncRNAs [103]) and NEAT1 are able to bind or interfere with different molecules and pathways depending on the tissue or disease (Table 1) $[77,106]$. MALAT1 acts as an miRNA sponge binding to miR-1271-5p (Figure 1), miR-181a-5p and miR-509-5p in MM, to miR-195 in HCC or to miR-206 and miR-363-3p in gallbladder cancer [63,65-68]. In the case of NEAT1, it binds to miR-125a in $\mathrm{MM}$ and to $m i R-193 a-3 p$ in lung adenocarcinoma, among others $[77,106]$. Usually, the expression of lncRNAs and miRNAs is negatively correlated. Therefore, overexpression of one lncRNA could trigger the downregulation of miRNAs, whereas downregulation of one lncRNA could promote the overexpression of different miRNAs [33,77]. Likewise, there are other examples of lncRNAs which act as miRNA sponges in MM (Table 1). In $\mathrm{MM}$, some of these lncRNAs, such as CRNDE (colorectal neoplasia differentially expressed) and IRAIN (IGF1R antisense imprinted non-protein coding RNA) are associated with the regulation of one single miRNA. However, an increasing number of studies in MM are showing that lncRNAs can regulate or can be regulated by more than one miRNA, such as H19 (H19 imprinted maternally expressed transcript), UCA1 (urothelial cancer associated 1) or OIP5-AS1 (OIP5 antisense RNA 1). Remarkably, there are cases like TUG1 (taurine upregulated 1) and $H 19$ that are associated with the regulation of the same miRNA, miR-29b-3p (Table 1) $[33,39,42,44,45,51,53,57-60,72,81-83,88,90,91,94-96]$. These results highlight the relevance of the miRNA sponge function of lncRNAs in MM.

Different studies have revealed how the knockdown or upregulation of certain lncRNAs is also associated with different biological and phenotypic effects in MM cells, such as the decrease in cell proliferation or viability, the decrease in cellular migration, the increase in cellular apoptosis and cell cycle arrest (Table 1).

Furthermore, various studies have demonstrated the in vivo biological effect of lncRNA knockdown in MM. For example, the inhibition of DARS-AS1 (DARS antisense RNA 1) or LINC00152 reduces the tumorigenesis of MM cells, whilst the knockdown of SOX2OT (SOX2 overlapping transcript) reduces tumor growth. Moreover, the knockdown of LINC01234 increases miR-124-3p and suppresses GRB2 expression, resulting in a decrease of cell proliferation and the inhibition of MM growth. These results demonstrate 
that IncRNAs play an important role in the pathobiology of MM (Table 1) [13,33-35,39$45,48,50,51,53,56-59,62,69,72,78,79,81-86,88,90-92,94-97,107]$.

\section{Impact of lncRNAs on the Response of MM}

As mentioned above, some lncRNAs interfere with the clinical response of MM patients to different drugs used for their treatment (Table 1). The knockdown of HOTAIR expression in MM cells triggers a decrease in chemoresistance to drugs such as dexamethasone, and the silencing of MIAT (myocardial infarction associated transcript) and PCAT-1 (prostate cancer associated transcript 1) sensitized MM cells to bortezomib $[43,48,49,75,76,83,84]$. It is interesting how HOTAIR and PCAT- 1 are associated with PRC2 epigenetic complex in other neoplasms. These two lncRNAs interact with PRC2, acting as epigenetic repressors of chromatin and inducing the reprogramming of genome chromatin states, or modulating gene transcription, respectively. Thus, it is possible that more lncRNAs and other transcripts that act by regulating or interfering with PRC2 could be also associated with resistance or sensitization to the treatment of MM patients. On the other hand, there are also lncRNAs that are not related to PRC2 but equally affect the treatment with bortezomib in MM patients. In this case, in vitro and in vivo approaches showed a better boosted anti-tumor effect for bortezomib in combination with the upregulation of PRAL in MM [86]. Likewise, the knockdown of PDIA3P and lnc-ANGPTL13 was associated with an increase of sensitivity to bortezomib treatment $[60,85]$, while the upregulation of DARS-AS1 reduced the sensitivity of MM cells to this drug [41]. Finally, the addition of bortezomib contributes to the upregulation of XLOC_013703 expression, triggering a decrease in cell proliferation in MM cells [97].

LncRNAs not only interact with PRC2 but also with a great variety of complexes and pathways (Table 1). For example, TUG1 can be transcriptionally regulated by p53 in response to DNA damage, and can target HDAC4, a histone deacetylase with an oncogenic role in MM [43,94]. PRAL also interacts with p53, promoting its upregulation [86,87], while IRAIN participates in the regulation of IGF-1 signaling [52]. In the case of MEG3, this lncRNA can induce cell apoptosis by both p53-dependent and p53-independent pathways [73]. DARS-AS1 interacts with HIP- $1 \alpha$, and their inhibition could trigger the suppression of the mTOR pathway [41]. LUCAT1 (lung cancer associated transcript 1) activates the TGF- $\beta$ pathway, promoting MM cell proliferation [62]. HOXB-AS1 (HOXB cluster antisense RNA 1) acts as a scaffold for ELAVL1, modulating the expression of FUT4, which could be affecting the Wnt/ $\beta$-catenin pathway [50]. MALAT1 acts as a scaffold for PARP1, helping to the repair of damaged DNA (Figure 1) [70]. These results indicate that lncRNAs directly impact on the response of MM patients to the drugs used for their treatment and suggest that their modulation could improve the response rates to the usual treatment schemes used in the therapy of these patients.

\section{IncRNAs as Biomarkers for Clinical Stratification of MM Patients}

Emerging studies have revealed the use of lncRNAs as biomarkers to improve the stratification of patients with different neoplasms, including MM (Table 1) [13,108]. In a recent study we demonstrated that the overexpression of PDLIM1P4, or the overexpression of PDLIM1P4 and ENSG00000249988, in combination with clinical and genetic risk factors, divided MM patients into different risk groups, associated with distinct levels of progression-free survival (PFS) and overall survival (OS), respectively [13]. Yin et al. described how high expression levels of ANRIL (antisense non-coding RNA in the INK4-ARF locus), combined with the downregulation of $m i R-34 a, m i R-125 a$ or $m i R-186$, were associated with worse PFS and OS in MM patients [33]. The overexpression of the cytoplasmic circular IncRNA Circ_0000190, MEG3 and PRAL has been associated with better PFS and OS, and high expression levels of SMILO (specific myeloma intergenic long non-coding RNA) with better OS in MM patients [13,36,72,86,87]. By contrast, high expression levels of lnc-TCF7, MALAT1, MIAT, NEAT1 and PDLIM1P4 have been associated with worse PFS and OS in MM patients $[13,61,63,70,75-77,80]$, the overexpression of CRNDE, LINC00152, LINC00461, 
LINC01234, lnc-ANGPTL1-3, PDIA3P and UCA1 with worse OS, and the overexpression of ENSG00000254343, H19 and NR_046683 (also known as ST3GAL6-AS1, ST3GAL6 antisense RNA 1) with worse PFS in MM patients $[13,40,46,56,85,93,95]$. In addition, high expression levels of LUCAT1 were associated with worse five-year survival rates [62], and MM patients with the lncRNA BM742401 methylated showed worse OS than those patients with unmethylated BM742401 [35]. These results suggest that lncRNAs could significantly contribute to the development of patient stratification tools, improving both the prognosis and monitoring of patients. However, more comprehensive studies are required to put into practice the use of panels of lncRNAs as biomarkers for the stratification of MM patients.

\section{Epigenetic Drugs can Modulate lncRNA Expression in MM}

The rising interest in lncRNAs has led to their consideration as attractive novel therapeutic targets for cancer treatment $[109,110]$. IncRNAs can form complex interaction networks with chromatin, RNA and proteins, regulating cellular pathways related to cancer hallmarks both directly and indirectly [109]. Therefore, lncRNA-targeted drugs may be an alternative strategy to modulate the activity of well-known oncoproteins, expanding the range of druggable targets for cancer treatment $[109,111]$.

$\mathrm{MM}$ is a heterogeneous disease, not only at the genetic but also at the epigenetic level. In fact, the way that the epigenetic changes can deregulate the transcription of IncRNAs has been described $[13,73]$. For example, recent studies have shown that the downregulation of $M E G 3$ in MM could be due to DNA hypermethylation of its promoter [72-74]. Then, the use of 5-Aza-2'-deoxycytidine could reverse the DNA hypermethylation of MEG3 promoter, triggering its re-expression and the inhibition of MM cell proliferation [74]. In the case of BM742401, this lncRNA was aberrantly DNA-methylated in MM, showing that methylated MM cell lines had lower expression of this lncRNA than unmethylated ones [35]. In contrast, the overexpression of SMILO can occur as a consequence of the DNA hypomethylation of its promoter and its transcription from an enhancer region with de novo gain of active chromatin marks in MM (Figure 2) [13]. In this direction, in the last few years, various studies have attempted to describe super-enhancers (SEs), clusters of active enhancers bound to more transcription factor (TF) binding sites than regular enhancers. SEs were first described in MM, where their oncogenic role has been demonstrated [112,113]. Strikingly, SEs could be transcribed into both enhancer lncRNAs (eRNAs) and super-enhancer lncRNAs (SE-lncRNAs), whose deregulation could also affect the development of MM [114]. These examples show the need to develop epigenetic drugs focused on epigenetically altered lncRNAs.

Interestingly, various studies have demonstrated that bromodomain and extraterminal inhibitors (BETis), such as JQ1, can regulate the transcription of enhancer regions or genes regulated by these enhancers [112]. These drugs act specifically on oncogenic SE sites, preventing the binding of their target proteins. BETis increase sensitivity to current therapies for MM, such as those using immunomodulatory drugs (IMiDs), proteasome inhibitors or JAK inhibitors. The combination of those treatments with BETis leads to a further reduction in the expression of oncogenic genes altered in MM, which can result in an increase in cellular apoptosis and anti-myeloma effect [115-117]. Specifically, in MM the treatment with JQ1 and lenalidomide triggers the decrease in MYC and IRF4 transcription, leading to reduced MM cell proliferation [113,118-120]. Thus, BETis could also be used to inhibit enhancer or SE regions of IncRNAs such as SMILO (Figure 2), which is aberrantly transcribed from a de novo enhancer region in MM [13]. In fact, several approaches have demonstrated the effect of these BETis on lncRNAs. For example, it has been described that JQ1 and CPI-203 can reduce the expression of the lncRNA PVT1 (Pvt1 oncogene) in different MM cell lines [89]. In addition to bromodomains, the PRC2 epigenetic complex is also known to interact with various lncRNAs, leading to the silencing of specific genomic loci. Hence, targeting this interaction could be an interesting approach to modulate downstream epigenetic changes exerted by PRC2 (Figure 2) [110]. In summary, 
this type of epigenetic therapy could be used to overcome the challenge of treatment resistances and the development of novel strategies against oncogenic lncRNAs in MM.
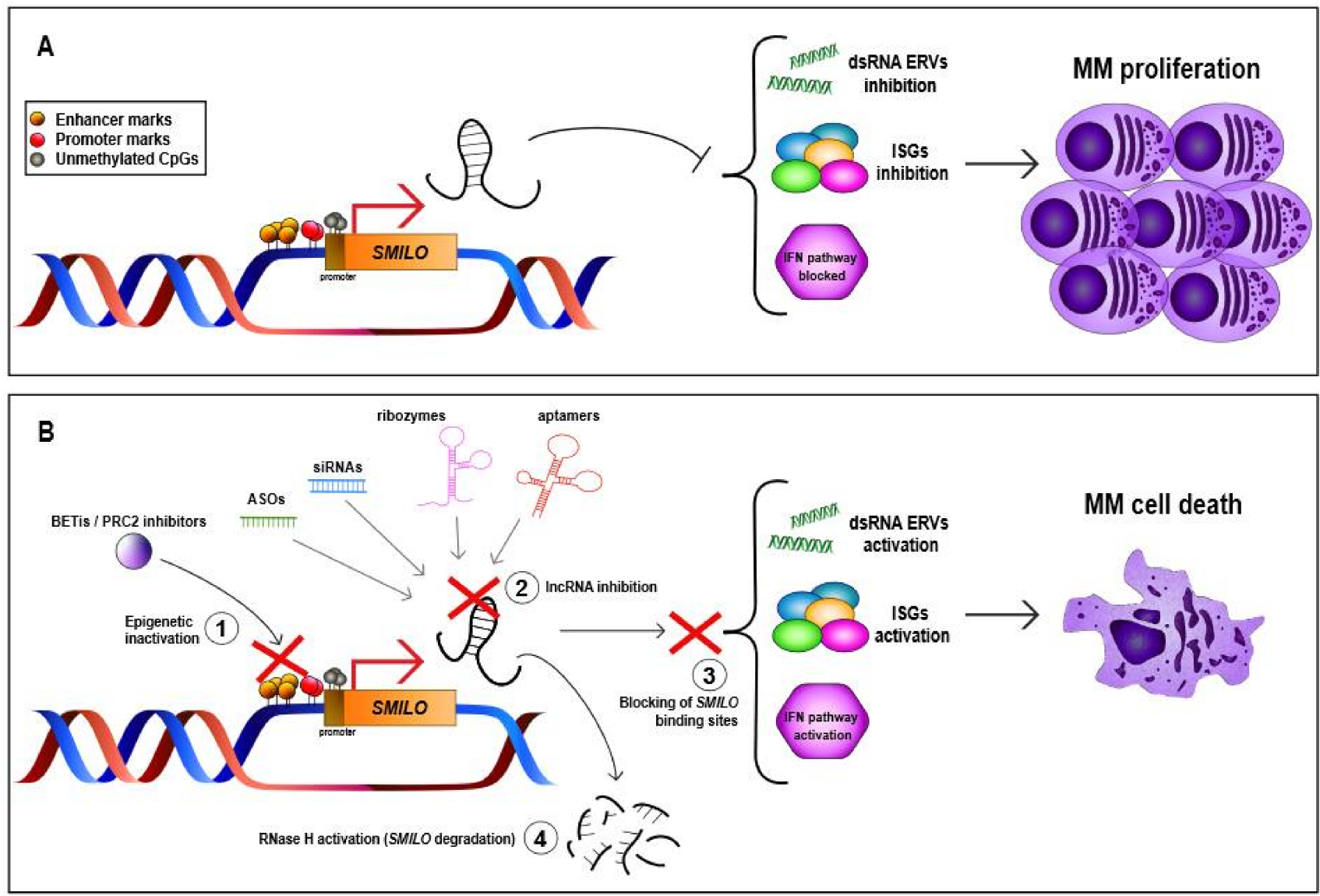

Figure 2. IncRNA-based strategies for MM treatment. (A) Gain of de novo active chromatin marks and DNA hypomethylation of the SMILO promoter leads to its overexpression in MM cells, triggering the inhibition of ERVs and ISGs and blocking the IFN pathway, resulting in MM cell proliferation. (B) Different strategies based on lncRNA-targeted therapies to block the effect of SMILO overexpression in MM cells, triggering cellular death. dsRNA = double-stranded RNA; ERVs = endogenous retroviruses; ISGs = interferon-stimulated genes; IFN = interferon; $\mathrm{MM}=$ multiple myeloma; BETis = bromodomain and extraterminal inhibitors; PRC2 = polycomb repressive complex 2.

\section{IncRNA-Targeted Therapies for MM Treatment}

In conjunction with the previously mentioned therapeutic strategies, there are currently several emergent RNA-based strategies that are becoming a major field of research, as they provide an effective way to target altered lncRNAs in certain diseases. RNAbased therapies exploit various effects exerted by oligonucleotides that bind RNA in a sequence-specific manner, which can result in target RNA degradation, alternative splicing redirection, protein production storage or defective RNA repair [121]. Although the majority of these strategies have been developed against coding mRNAs, virtually all RNA species could be targeted equally. By 2020, ten oligonucleotide-based drugs had been approved by the FDA/EMA for the treatment of various genetic diseases, and more than 20 novel compounds are currently being evaluated in clinical trials [122]. However, although a small number of these agents has been selected to target different tumors, preclinical studies have revealed their potential as novel anticancer targeted agents against tumor-specific targets, or even subtype-specific targets [123-125].

One of the main strategies involves the knockdown of target deleterious lncRNAs (Figure 2). This can be achieved by specifically designed siRNAs or antisense oligonucleotides (ASOs), which form a heteroduplex with target RNA leading to RNAse H recognition and cleavage. In comparison to conventional siRNAs, ASOs show various advantages, 
such as higher specificity, reduced off-target effects and RISC complex independence. Alternatively, ribozymes or deoxyribozymes could be used to target lncRNAs that are unfavorable for effective oligonucleotide synthesis due to extensive secondary structures or short length (Figure 2). So far, several studies have successfully attempted to inhibit oncogenic lncRNAs by means of siRNAs or ASOs in the context of cancer treatment (Figure 2) [110]. Regarding MM, some of these oncogenic IncRNAs have been successfully targeted for MM treatment. The most prominent example is the one provided by MALAT1, whose druggability has been shown by two independent studies that targeted it with LNA gapmer ASOs both in vitro and in vivo. The degradation of MALAT1 in vitro, both in cell lines and patient-derived MM plasma cells, induced DNA damage and apoptosis leading to impaired MM proliferation, while in vivo it increased the survival of MM-bearing mice $[69,70]$. Besides, Hu et al. conjugated the anti-MALAT1 ASOs with single-wall carbon nanotubes (SWCNT), allowing the in vivo release of the drug at high concentrations in MM cells without signals of toxicity in normal cells, which revealed SWCNT as a novel nanomaterial for effective drug delivery [70]. Similarly, a recent study by Taiana et al. showed that NEAT1 knockdown with ASOs triggered the inhibition of MM cell proliferation and an increase in cellular apoptosis. Furthermore, NEAT1 inhibition was associated with a chemo-sensitizing effect of both conventional and novel therapeutics, pointing to the interest of targeting NEAT1 to enhance the effects of novel combination therapies [78].

But oligonucleotide therapies are not only aimed at the inhibition of overexpressed targets. Indeed, splice-switching oligonucleotides may be used to excise exons that encode essential lncRNA functional domains, rendering oncogenic lncRNAs unable to exert their functions. Alternatively, steric blocking oligonucleotides may block the binding of lncRNAs to their binding partners (Figure 2) [109]. Although these strategies have been poorly exploited, they will definitely expand the range of appealing non-coding therapeutic targets for cancer treatment.

However, the development of RNA-based therapeutics still needs to overcome several obstacles if it is going to be translated into clinical practice [110]. In fact, one of the greatest challenges for oligonucleotide therapies is the effective delivery of these agents to target cells. To date, most approved oligonucleotide drugs are focused either on hepatic delivery or local delivery to the eye or the spinal cord, with extra-hepatic delivery remaining a major goal in the field [122]. With the aim of overcoming this obstacle, therapeutic oligonucleotides are chemically modified to improve their drug-like properties. Furthermore, they can be conjugated to a variety of carrier molecules such as aptamers, nanoparticles, antibodies, lipid conjugates, exosomes, peptides or DNA nanostructures, which can promote intracellular uptake, reduce renal clearance from circulation or enhance delivery to the target cells [122]. Among these carriers, aptamers constitute an attractive therapeutic approach due to their unique properties for targeted delivery (Figure 2). These biomolecules combine the flexibility of small molecules with the specificity of antibodies, therefore expanding the range of druggable targets and offering novel solutions to overcome the actual hurdles in targeted delivery [126]. The combination of specific regulatory oligonucleotides with the adequate carriers for selected cells/tissues will enable us to reach previously inaccessible tissues and targets. In this sense, IncRNAs constitute a novel entity of functional transcripts in the cell with demonstrated therapeutic potential. The development of a universal RNA-based therapeutic platform will enable the rapid development of drugs directed to novel target lncRNAs. Therefore, oligonucleotide drugs could be developed against virtually any novel oncogenic lncRNA, undoubtedly expanding the range of druggable targets and leading the way to personalized medicine in tumor treatment in order to respond to unmet clinical needs.

\section{Conclusions}

MM is a heterogeneous disease that needs integrative multidisciplinary studies to shed light on its inter-individual variability. The coding transcriptome of MM is wellcharacterized, but more high-throughput studies on the lncRNA transcriptome are needed 
in order to detect all the deregulated lncRNAs that might have an important role in the biology of MM cells, leading to the identification of potential disease biomarkers. Furthermore, functional studies will elucidate their functions and the pathways in which these deregulated lncRNAs are involved, paving the way for the development of novel targeted therapeutic strategies against lncRNAs, as well as for the devising of more effective combination therapies to improve the response and life quality of MM patients.

Author Contributions: Conceptualization, A.C.-L., A.A., F.P. and X.A.; writing-original draft preparation, A.C.-L., A.A., N.G.-E. and X.A.; writing-review and editing, A.C.-L., F.P. and X.A. All authors have read and agreed to the published version of the manuscript.

Funding: This study was funded by grants from Instituto de Salud Carlos III (ISCIII) and co-financed by FEDER: PI17/00701, PI19/01352 and CIBERONC CB16/12/00489, with support from 616/C/2019 Fundació La Marató de TV3, Cancer Research UK [C355/A26819] and FC AECC and AIRC under the Accelerator Award Programme, the Multiple Myeloma Research Foundation Networks of Excellence 2017 Immunotherapy Program Grant Award, the International Myeloma Foundation (Brian van Novis), the Qatar National Research Fund award 7-916-3-237 and Paula and Rodger Riney Foundation. A.C-L. was supported by the ISCIII and FSE (FI16/00275) awards from ISCIII, A.A. by an FPU (FPU17/02733) grant from Ministerio de Ciencia, Innovación y Universidades, Gobierno de España, and N.G-E. by the Ayudas Predoctorales de Investigación Biomédica AC from FIMA.

Conflicts of Interest: The authors declare no conflict of interest.

\section{References}

1. Morgan, G.J.; Walker, B.A.; Davies, F.E. The genetic architecture of multiple myeloma. Nat. Rev. Cancer 2012, 12, 335-348. [CrossRef] [PubMed]

2. Kumar, S.K.; Rajkumar, V.; Kyle, R.A.; Van Duin, M.; Sonneveld, P.; Mateos, M.-V.; Gay, F.; Anderson, K.C. Multiple myeloma. Nat. Rev. Dis. Prim. 2017, 3, 17046. [CrossRef] [PubMed]

3. Castaneda, O.; Baz, R. Multiple Myeloma Genomics-A Concise Review. Acta Med. Acad. 2019, 48, 57-67. [CrossRef] [PubMed]

4. Medical Masterclass Contributors; Firth, J. Haematology: Multiple myeloma. Clin. Med. 2019, 19, 58-60. [CrossRef]

5. Agirre, X.; Castellano, G.; Pascual, M.; Heath, S.; Kulis, M.; Segura, V.; Bergmann, A.; Esteve, A.; Merkel, A.; Raineri, E.; et al. Whole-epigenome analysis in multiple myeloma reveals DNA hypermethylation of B cell-specific enhancers. Genome Res. 2015, 25, 478-487. [CrossRef]

6. Manier, S.; Salem, K.Z.; Park, J.; Landau, D.A.; Getz, G.; Ghobrial, I.M. Genomic complexity of multiple myeloma and its clinical implications. Nat. Rev. Clin. Oncol. 2017, 14, 100-113. [CrossRef]

7. Prideaux, S.M.; O’Brien, E.C.; Chevassut, T.J. The Genetic Architecture of Multiple Myeloma. Adv. Hematol. 2014, $2014,864058$. [CrossRef]

8. Barwick, B.G.; Neri, P.; Bahlis, N.J.; Nooka, A.K.; Dhodapkar, M.V.; Jaye, D.L.; Hofmeister, C.C.; Kaufman, J.L.; Gupta, V.A.; Auclair, D.; et al. Multiple myeloma immunoglobulin lambda translocations portend poor prognosis. Nat. Commun. 2019, 10, 1911. [CrossRef]

9. Rajkumar, S.V. Multiple myeloma: Every year a new standard? Hematol. Oncol. 2019, 37 (Suppl. 1), 62-65. [CrossRef]

10. Ordoñez, R.; Kulis, M.; Russiñol, N.; Chapaprieta, V.; Carrasco-Leon, A.; García-Torre, B.; Charalampopoulou, S.; Clot, G.; Beekman, R.; Meydan, C.; et al. Chromatin activation as a unifying principle underlying pathogenic mechanisms in multiple myeloma. Genome Res. 2020, 30, 1217-1227. [CrossRef]

11. Beekman, R.; Chapaprieta, V.; Russiñol, N.; Vilarrasa-Blasi, R.; Verdaguer-Dot, N.; Martens, J.H.A.; Duran-Ferrer, M.; Kulis, M.; Serra, F.; Javierre, B.M.; et al. The reference epigenome and regulatory chromatin landscape of chronic lymphocytic leukemia. Nat. Med. 2018, 24, 868-880. [CrossRef]

12. Ernst, J.; Kheradpour, P.; Mikkelsen, T.S.; Shoresh, N.; Ward, L.D.; Epstein, C.B.; Zhang, X.; Wang, L.; Issner, R.; Coyne, M.; et al. Mapping and analysis of chromatin state dynamics in nine human cell types. Nature 2011, 473, 43-49. [CrossRef]

13. Carrasco-Leon, A.; Ezponda, T.; Meydan, C.; Valcárcel, L.V.; Ordoñez, R.; Kulis, M.; Garate, L.; Miranda, E.; Segura, V.; Guruceaga, E.; et al. Characterization of complete lncRNAs transcriptome reveals the functional and clinical impact of lncRNAs in multiple myeloma. Leukemia 2021, 1-13. [CrossRef]

14. Ng, M.; Heckl, D.; Klusmann, J.-H. The Regulatory Roles of Long Noncoding RNAs in Acute Myeloid Leukemia. Front. Oncol. 2019, 9, 570. [CrossRef]

15. Quinn, J.J.; Chang, H.Y. Unique features of long non-coding RNA biogenesis and function. Nat. Rev. Genet. $2016,17,47-62$. [CrossRef]

16. Garitano-Trojaola, A.; José-Enériz, E.S.; Ezponda, T.; Unfried, J.P.; Carrasco-León, A.; Razquin, N.; Barriocanal, M.; Vilas-Zornoza, A.; Sangro, B.; Segura, V.; et al. Deregulation of linc-PINT in acute lymphoblastic leukemia is implicated in abnormal proliferation of leukemic cells. Oncotarget 2018, 9, 12842-12852. [CrossRef] 
17. Robinson, E.K.; Covarrubias, S.; Carpenter, S. The how and why of lncRNA function: An innate immune perspective. Biochim. Biophys. Acta Bioenerg. 2020, 1863, 194419. [CrossRef]

18. Jarroux, J.; Morillon, A.; Pinskaya, M. History, Discovery, and Classification of lncRNAs. Adv. Exp. Med. Biol. 2017, 1008, 1-46. [CrossRef]

19. Derrien, T.; Johnson, R.; Bussotti, G.; Tanzer, A.; Djebali, S.; Tilgner, H.; Guernec, G.; Martin, D.; Merkel, A.; Knowles, D.G.; et al. The GENCODE v7 catalog of human long noncoding RNAs: Analysis of their gene structure, evolution, and expression. Genome Res. 2012, 22, 1775-1789. [CrossRef]

20. Laurent, G.S.; Vyatkin, Y.; Antonets, D.; Ri, M.; Qi, Y.; Saik, O.; Shtokalo, D.; De Hoon, M.J.; Kawaji, H.; Itoh, M.; et al. Functional annotation of the vlinc class of non-coding RNAs using systems biology approach. Nucleic Acids Res. 2016, 44, $3233-3252$. [CrossRef]

21. Bhan, A.; Mandal, S.S. LncRNA HOTAIR: A master regulator of chromatin dynamics and cancer. Biochim. Biophys. Acta Bioenerg. 2015, 1856, 151-164. [CrossRef]

22. Kopp, F.; Mendell, J.T. Functional Classification and Experimental Dissection of Long Noncoding RNAs. Cell 2018, $172,393-407$. [CrossRef]

23. Yan, P.; Luo, S.; Lu, J.Y.; Shen, X. Cis- and trans-acting lncRNAs in pluripotency and reprogramming. Curr. Opin. Genet. Dev. 2017, 46, 170-178. [CrossRef]

24. Guenzl, P.M.; Barlow, D.P. Macro lncRNAs: A new layer of cis-regulatory information in the mammalian genome. RNA Biol. 2012, 9,731-741. [CrossRef]

25. Agirre, X.; Meydan, C.; Jiang, Y.; Garate, L.; Doane, A.S.; Li, Z.; Verma, A.; Paiva, B.; Martín-Subero, J.I.; Elemento, O.; et al. Long non-coding RNAs discriminate the stages and gene regulatory states of human humoral immune response. Nat. Commun. 2019, 10, 821. [CrossRef]

26. Wang, K.C.; Chang, H.Y. Molecular Mechanisms of Long Noncoding RNAs. Mol. Cell 2011, 43, 904-914. [CrossRef]

27. Shi, W.; Wang, Q.; Bian, Y.; Fan, Y.; Zhou, Y.; Feng, T.; Li, Z.; Cao, X. Long noncoding RNA PANDA promotes esophageal squamous carcinoma cell progress by dissociating from NF-YA but interact with SAFA. Pathol. Res. Pract. 2019, $215,152604$. [CrossRef]

28. Calle, A.S.; Kawamura, Y.; Yamamoto, Y.; Takeshita, F.; Ochiya, T. Emerging roles of long non-coding RNA in cancer. Cancer Sci. 2018, 109, 2093-2100. [CrossRef]

29. Akhade, V.S.; Pal, D.; Kanduri, C. Long Noncoding RNA: Genome Organization and Mechanism of Action. Adv. Exp. Med. Biol. 2017, 1008, 47-74. [CrossRef]

30. Chen, C.-L.; Tseng, Y.-W.; Wu, J.-C.; Chen, G.-Y.; Lin, K.-C.; Hwang, S.-M.; Hu, Y.-C. Suppression of hepatocellular carcinoma by baculovirus-mediated expression of long non-coding RNA PTENP1 and MicroRNA regulation. Biomaterials 2015, 44, 71-81. [CrossRef] [PubMed]

31. Balas, M.M.; Johnson, A.M. Exploring the mechanisms behind long noncoding RNAs and cancer. Non-Coding RNA Res. 2018, 3 , 108-117. [CrossRef] [PubMed]

32. Hermans-Beijnsberger, S.; van Bilsen, M.; Schroen, B. Long non-coding RNAs in the failing heart and vasculature. Non-Coding RNA Res. 2018, 3, 118-130. [CrossRef] [PubMed]

33. Yin, Y.; Yang, W.; Zhang, L.; Liu, K.; Luo, Z. Long non-coding RNA ANRIL and its target microRNAs (microRNA-34a, microRNA125a and microRNA-186) relate to risk stratification and prognosis in multiple myeloma. Hematology 2021, 26, 160-169. [CrossRef] [PubMed]

34. Wang, M.; Zhao, H.-Y.; Zhang, J.-L.; Wan, D.-M.; Li, Y.-M.; Jiang, Z.-X. Dysregulation of LncRNA ANRIL mediated by miR-411-3p inhibits the malignant proliferation and tumor stem cell like property of multiple myeloma via hypoxia-inducible factor $1 \alpha$. Exp. Cell Res. 2020, 396, 112280. [CrossRef]

35. Li, Z.; Kumar, S.; Jin, D.-Y.; Calin, G.A.; Chng, W.-J.; Siu, K.-L.; Poon, M.-W.; Chim, C.S. Epigenetic silencing of long non-coding RNA BM742401 in multiple myeloma: Impact on prognosis and myeloma dissemination. Cancer Cell Int. 2020, 20, 403. [CrossRef]

36. Feng, Y.; Zhang, L.; Wu, J.; Khadka, B.; Fang, Z.; Gu, J.; Tang, B.; Xiao, R.; Pan, G.; Liu, J. CircRNA circ_0000190 inhibits the progression of multiple myeloma through modulating miR-767-5p/MAPK4 pathway. J. Exp. Clin. Cancer Res. 2019, 38, 54. [CrossRef]

37. Chen, S.; Li, T.; Zhao, Q.; Xiao, B.; Guo, J. Using circular RNA hsa_circ_0000190 as a new biomarker in the diagnosis of gastric cancer. Clin. Chim. Acta 2017, 466, 167-171. [CrossRef]

38. Luo, Y.-H.; Yang, Y.-P.; Chien, C.-S.; Yarmishyn, A.A.; Ishola, A.A.; Chien, Y.; Chen, Y.-M.; Huang, T.-W.; Lee, K.-Y.; Huang, W.-C.; et al. Plasma Level of Circular RNA hsa_circ_0000190 Correlates with Tumor Progression and Poor Treatment Response in Advanced Lung Cancers. Cancers 2020, 12, 1740. [CrossRef]

39. Meng, Y.-B.; He, X.; Huang, Y.-F.; Wu, Q.-N.; Zhou, Y.-C.; Hao, D.-J. Long Noncoding RNA CRNDE Promotes Multiple Myeloma Cell Growth by Suppressing miR-451. Oncol. Res. Featur. Preclin. Clin. Cancer Ther. 2017, 25, 1207-1214. [CrossRef]

40. David, A.; Zocchi, S.; Talbot, A.; Choisy, C.; Ohnona, A.; Lion, J.; Cuccuini, W.; Soulier, J.; Arnulf, B.; Bories, J.-C.; et al. The long non-coding RNA CRNDE regulates growth of multiple myeloma cells via an effect on IL6 signalling. Leukemia 2020. [CrossRef]

41. Tong, J.; Xu, X.; Zhang, Z.; Ma, C.; Xiang, R.; Liu, J.; Xu, W.; Wu, C.; Li, J.; Zhan, F.; et al. Hypoxia-induced long non-coding RNA DARS-AS1 regulates RBM39 stability to promote myeloma malignancy. Haematologica 2020, 105, 1630-1640. [CrossRef] 
42. Li, Q.-Y.; Chen, L.; Hu, N.; Zhao, H. Long non-coding RNA FEZF1-AS1 promotes cell growth in multiple myeloma via miR610/Akt3 axis. Biomed. Pharmacother. 2018, 103, 1727-1732. [CrossRef]

43. Isin, M.; Ozgur, E.; Cetin, G.; Erten, N.; Aktan, M.; Gezer, U.; Dalay, N. Investigation of circulating lncRNAs in B-cell neoplasms. Clin. Chim. Acta 2014, 431, 255-259. [CrossRef]

44. Pan, Y.; Zhang, Y.; Liu, W.; Huang, Y.; Shen, X.; Jing, R.; Pu, J.; Wang, X.; Ju, S.; Cong, H.; et al. LncRNA H19 overexpression induces bortezomib resistance in multiple myeloma by targeting MCL-1 via miR-29b-3p. Cell Death Dis. 2019, 10, 106. [CrossRef]

45. Zheng, J.-F.; Guo, N.-H.; Zi, F.-M.; Cheng, J. Long Noncoding RNA H19 Promotes Tumorigenesis of Multiple Myeloma by Activating BRD4 Signaling by Targeting MicroRNA 152-3p. Mol. Cell. Biol. 2019, 40. [CrossRef]

46. Pan, Y.; Chen, H.; Shen, X.; Wang, X.; Ju, S.; Lu, M.; Cong, H. Serum level of long noncoding RNA H19 as a diagnostic biomarker of multiple myeloma. Clin. Chim. Acta 2018, 480, 199-205. [CrossRef]

47. Tang, Q.; Hann, S.S. HOTAIR: An Oncogenic Long Non-Coding RNA in Human Cancer. Cell. Physiol. Biochem. 2018, 47, 893-913. [CrossRef]

48. Zhu, B.Z.; Lin, L. Effects of lncRNA HOTAIR on proliferation and apoptosis of myeloma cells through NF-kB pathway. Eur. Rev. Med. Pharmacol. Sci. 2019, 23, 10042-10048. [CrossRef]

49. Guan, R.; Wang, W.; Fu, B.; Pang, Y.; Lou, Y.; Li, H. Increased lncRNA HOTAIR expression promotes the chemoresistance of multiple myeloma to dexamethasone by regulating cell viability and apoptosis by mediating the JAK2/STAT3 signaling pathway. Mol. Med. Rep. 2019, 20, 3917-3923. [CrossRef]

50. Chen, R.; Zhang, X.; Wang, C. LncRNA HOXB-AS1 promotes cell growth in multiple myeloma via FUT4 mRNA stability by ELAVL1. J. Cell. Biochem. 2019, 121, 4043-4051. [CrossRef]

51. Jiang, Y.; Chen, J.; Chen, G. Long noncoding RNA IRAIN acts as tumor suppressor via miR-125b in multiple myeloma. Oncol. Lett. 2019, 18, 6787-6794. [CrossRef] [PubMed]

52. Feng, J.; Sun, Y.; Zhang, E.-B.; Lu, X.-Y.; Jin, S.-D.; Guo, R.-H. A novel long noncoding RNA IRAIN regulates cell proliferation in non small cell lung cancer. Int. J. Clin. Exp. Pathol. 2015, 8, 12268-12275. [PubMed]

53. Yu, T.; Xu, Z.; Zhang, X.; Men, L.; Nie, H. Long intergenic non-protein coding RNA 152 promotes multiple myeloma progression by negatively regulating microRNA-497. Oncol. Rep. 2018, 40, 3763-3771. [CrossRef] [PubMed]

54. Ji, D.; Wang, Y.; Li, H.; Sun, B.; Luo, X. Long non-coding RNA LINC00461/miR-149-5p/LRIG2 axis regulates hepatocellular carcinoma progression. Biochem. Biophys. Res. Commun. 2019, 512, 176-181. [CrossRef]

55. Meng, Q.; Liu, M.; Cheng, R. LINC00461/miR-4478/E2F1 feedback loop promotes non-small cell lung cancer cell proliferation and migration. Biosci. Rep. 2020, 40. [CrossRef]

56. Deng, M.; Yuan, H.; Liu, S.; Hu, Z.; Xiao, H. Exosome-transmitted LINC00461 promotes multiple myeloma cell proliferation and suppresses apoptosis by modulating microRNA/BCL-2 expression. Cytotherapy 2019, 21, 96-106. [CrossRef]

57. Lu, D.; Yang, C.; Zhang, Z.; Cong, Y.; Xiao, M. Knockdown of Linc00515 Inhibits Multiple Myeloma Autophagy and Chemoresistance by Upregulating miR-140-5p and Downregulating ATG14. Cell. Physiol. Biochem. 2018, 48, 2517-2527. [CrossRef]

58. Wang, C.; Li, M.; Wang, S.; Jiang, Z.; Liu, Y. LINC00665 Promotes the Progression of Multiple Myeloma by Adsorbing miR-214-3p and Positively Regulating the Expression of PSMD10 and ASF1B. OncoTargets Ther. 2020, 13, 6511-6522. [CrossRef]

59. Chen, X.; Liu, Y.; Yang, Z.; Zhang, J.; Chen, S.; Cheng, J. LINC01234 promotes multiple myeloma progression by regulating miR-124-3p/GRB2 axis. Am. J. Transl. Res. 2019, 11, 6600-6618.

60. Nian, F.; Zhu, J.; Chang, H. Long non-coding RNA ANGPTL1-3 promotes multiple myeloma bortezomib resistance by sponging miR-30a-3p to activate c-Maf expression. Biochem. Biophys. Res. Commun. 2019, 514, 1140-1146. [CrossRef]

61. Zhang, C.; Chu, M.; Fan, Y.; Wu, L.; Li, Z.; Ma, X.; Zhuang, W. Long non-coding RNA T-cell factor 7 in multiple myeloma: A potential biomarker for deteriorated clinical features and poor prognosis. J. Clin. Lab. Anal. 2020, 34, e23400. [CrossRef]

62. Liu, Z.; Gao, H.; Peng, Q.; Yang, Y. Long Noncoding RNA LUCAT1 Promotes Multiple Myeloma Cell Growth by Regulating the TGF- $\beta$ Signaling Pathway. Technol. Cancer Res. Treat. 2020, 19, 1533033820945770. [CrossRef]

63. Handa, H.; Kuroda, Y.; Kimura, K.; Masuda, Y.; Hattori, H.; Alkebsi, L.; Matsumoto, M.; Kasamatsu, T.; Kobayashi, N.; Tahara, K.-I.; et al. Long non-coding RNAMALAT1is an inducible stress response gene associated with extramedullary spread and poor prognosis of multiple myeloma. Br. J. Haematol. 2017, 179, 449-460. [CrossRef]

64. Zhao, M.; Wang, S.; Li, Q.; Ji, Q.; Guo, P.; Liu, X. MALAT1: A long non-coding RNA highly associated with human cancers. Oncol. Lett. 2018, 16, 19-26. [CrossRef]

65. Li, Z.-X.; Zhu, Q.-N.; Zhang, H.-B.; Hu, Y.; Wang, G.; Zhu, Y.-S. MALAT1: A potential biomarker in cancer. Cancer Manag. Res. 2018, 10, 6757-6768. [CrossRef]

66. Gu, Y.; Xiao, X.; Yang, S. LncRNA MALAT1 acts as an oncogene in multiple myeloma through sponging miR-509-5p to modulate FOXP1 expression. Oncotarget 2017, 8, 101984-101993. [CrossRef]

67. Liu, N.; Feng, S.; Li, H.; Chen, X.; Bai, S.; Liu, Y. Long non-coding RNA MALAT1 facilitates the tumorigenesis, invasion and glycolysis of multiple myeloma via miR-1271-5p/SOX13 axis. J. Cancer Res. Clin. Oncol. 2020, 146, 367-379. [CrossRef]

68. Sun, Y.; Jiang, T.; Jia, Y.; Zou, J.; Wang, X.; Gu, W. LncRNA MALAT1/miR-181a-5p affects the proliferation and adhesion of myeloma cells via regulation of Hippo-YAP signaling pathway. Cell Cycle 2019, 18, 2509-2523. [CrossRef]

69. Amodio, N.; Stamato, M.A.; Juli, G.; Morelli, E.; Fulciniti, M.; Manzoni, M.; Taiana, E.; Agnelli, L.; Cantafio, M.E.G.; Romeo, E.; et al. Drugging the lncRNA MALAT1 via LNA gapmeR ASO inhibits gene expression of proteasome subunits and triggers anti-multiple myeloma activity. Leukemia 2018, 32, 1948-1957. [CrossRef] 
70. Hu, Y.; Lin, J.; Fang, H.; Fang, J.; Li, C.; Chen, W.; Liu, S.; Ondrejka, S.; Gong, Z.; Reu, F.; et al. Targeting the MALAT1/PARP1/LIG3 complex induces DNA damage and apoptosis in multiple myeloma. Leukemia 2018, 32, 2250-2262. [CrossRef]

71. Zhuang, W.; Ge, X.; Yang, S.; Huang, M.; Zhuang, W.; Chen, P.; Zhang, X.; Fu, J.; Qu, J.; Li, B. Upregulation of lncRNA MEG3 Promotes Osteogenic Differentiation of Mesenchymal Stem Cells from Multiple Myeloma Patients by Targeting BMP4 Transcription. Stem Cells 2015, 33, 1985-1997. [CrossRef]

72. Shen, X.; Bai, H.; Zhu, H.; Yan, Q.; Yang, Y.; Yu, W.; Shi, Q.; Wang, J.; Li, J.; Chen, L. Long Non-Coding RNA MEG3 Functions as a Competing Endogenous RNA to Regulate HOXA11 Expression by Sponging miR-181a in Multiple Myeloma. Cell. Physiol. Biochem. 2018, 49, 87-100. [CrossRef]

73. Benetatos, L.; Dasoula, A.; Hatzimichael, E.; Georgiou, I.; Syrrou, M.; Bourantas, K.L. Promoter Hypermethylation of the MEG3 (DLK1/MEG3) Imprinted Gene in Multiple Myeloma. Clin. Lymphoma Myeloma 2008, 8, 171-175. [CrossRef]

74. Yu, W.; Shi, Q.; Wu, C.; Shen, X.; Chen, L.; Xu, J. Promoter hypermethylation influences the suppressive role of long non-coding RNA MEG3 in the development of multiple myeloma. Exp. Ther. Med. 2020, 20, 637-645. [CrossRef]

75. Ronchetti, D.; Agnelli, L.; Pietrelli, A.; Todoerti, K.; Manzoni, M.; Taiana, E.; Neri, A. A compendium of long non-coding RNAs transcriptional fingerprint in multiple myeloma. Sci. Rep. 2018, 8, 6557. [CrossRef]

76. Fu, Y.; Liu, X.; Zhang, F.; Jiang, S.; Liu, J.; Luo, Y. Bortezomib-inducible long non-coding RNA myocardial infarction associated transcript is an oncogene in multiple myeloma that suppresses miR-29b. Cell Death Dis. 2019, 10, 319. [CrossRef]

77. Yu, H.; Peng, S.; Chen, X.; Han, S.; Luo, J. Long non-coding RNA NEAT1 serves as a novel biomarker for treatment response and survival profiles via microRNA-125a in multiple myeloma. J. Clin. Lab. Anal. 2020, 34, e23399. [CrossRef]

78. Taiana, E.; Favasuli, V.; Ronchetti, D.; Todoerti, K.; Pelizzoni, F.; Manzoni, M.; Barbieri, M.; Fabris, S.; Silvestris, I.; Cantafio, M.E.G.; et al. Long non-coding RNA NEAT1 targeting impairs the DNA repair machinery and triggers anti-tumor activity in multiple myeloma. Leukemia 2020, 34, 234-244. [CrossRef]

79. Taiana, E.; Ronchetti, M.; Favasuli, V.; Todoerti, K.; Manzoni, M.; Amodio, N.; Tassone, P.; Agnelli, L.; Neri, A. Long non-coding RNA NEAT1 shows high expression unrelated to molecular features and clinical outcome in multiple myeloma. Haematologica 2019, 104, e72-e76. [CrossRef]

80. Gao, Y.; Fang, P.; Li, W.-J.; Zhang, J.; Wang, G.-P.; Jiang, D.-F.; Chen, F.-P. LncRNA NEAT1 sponges miR-214 to regulate M2 macrophage polarization by regulation of B7-H3 in multiple myeloma. Mol. Immunol. 2020, 117, 20-28. [CrossRef]

81. Wang, Y.; Wang, H.; Ruan, J.; Zheng, W.; Yang, Z.; Pan, W. Long non-coding RNA OIP5-AS1 suppresses multiple myeloma progression by sponging miR-27a-3p to activate TSC1 expression. Cancer Cell Int. 2020, 20, 155. [CrossRef] [PubMed]

82. Yang, N.; Chen, J.; Zhang, H.; Wanggang, Z.; Yao, H.; Peng, Y.; Zhang, W. LncRNA OIP5-AS1 loss-induced microRNA-410 accumulation regulates cell proliferation and apoptosis by targeting KLF10 via activating PTEN/PI3K/AKT pathway in multiple myeloma. Cell Death Dis. 2017, 8, e2975. [CrossRef] [PubMed]

83. Shen, X.; Kong, S.; Yang, Q.; Yin, Q.; Cong, H.; Wang, X.; Ju, S. PCAT-1 promotes cell growth by sponging miR-129 via MAP3K7/NF-кB pathway in multiple myeloma. J. Cell. Mol. Med. 2020, 24, 3492-3503. [CrossRef] [PubMed]

84. Shen, X.; Shen, P.; Yang, Q.; Yin, Q.; Wang, F.; Cong, H.; Wang, X.; Ju, S. Knockdown of long non-coding RNA PCAT-1 inhibits myeloma cell growth and drug resistance via p38 and JNK MAPK pathways. J. Cancer 2019, 10, 6502-6510. [CrossRef]

85. Yang, X.; Ye, H.; He, M.; Zhou, X.; Sun, N.; Guo, W.; Lin, X.; Huang, H.; Lin, Y.; Yao, R.; et al. LncRNA PDIA3P interacts with c-Myc to regulate cell proliferation via induction of pentose phosphate pathway in multiple myeloma. Biochem. Biophys. Res. Commun. 2018, 498, 207-213. [CrossRef]

86. Xiao, G.; Li, Y.; Wang, Y.; Zhao, B.; Zou, Z.; Hou, S.; Jia, X.; Liu, X.; Yao, Y.; Wan, J.; et al. LncRNA PRAL is closely related to clinical prognosis of multiple myeloma and the bortezomib sensitivity. Exp. Cell Res. 2018, 370, 254-263. [CrossRef]

87. Wen, Y.-Y.; Bai, B.; Hu, X.-S. Expression and Clinical Significance of Long Non-Coding RNA PRAL in Patients with Multiple Myeloma. Zhongguo Shi Yan Xue Ye Xue Za Zhi 2020, 28, 185-190. [CrossRef]

88. Yang, M.; Zhang, L.; Wang, X.; Zhou, Y.; Wu, S. Down-regulation of miR-203a by lncRNA PVT1 in multiple myeloma promotes cell proliferation. Arch. Med Sci. 2018, 14, 1333-1339. [CrossRef]

89. Handa, H.; Honma, K.; Oda, T.; Kobayashi, N.; Kuroda, Y.; Kimura-Masuda, K.; Watanabe, S.; Ishihara, R.; Murakami, Y.; Masuda, Y.; et al. Long Noncoding RNA PVT1 Is Regulated by Bromodomain Protein BRD4 in Multiple Myeloma and Is Associated with Disease Progression. Int. J. Mol. Sci. 2020, 21, 7121. [CrossRef]

90. Yang, X.; Huang, H.; Wang, X.; Liu, H.; Liu, H.; Lin, Z. Knockdown of lncRNA SNHG16 suppresses multiple myeloma cell proliferation by sponging miR-342-3p. Cancer Cell Int. 2020, 20, 38. [CrossRef]

91. Tianhua, Y.; Dianqiu, L.; Xuanhe, Z.; Zhe, Z.; Dongmei, G. Long non-coding RNA Sox2 overlapping transcript (SOX2OT) promotes multiple myeloma progression via microRNA-143-3p/c-MET axis. J. Cell. Mol. Med. 2020, 24, 5185-5194. [CrossRef]

92. Ronchetti, D.; Todoerti, K.; Vinci, C.; Favasuli, V.; Agnelli, L.; Manzoni, M.; Pelizzoni, F.; Chiaramonte, R.; Platonova, N.; Giuliani, N.; et al. Expression Pattern and Biological Significance of the lncRNA ST3GAL6-AS1 in Multiple Myeloma. Cancers 2020, $12,782$. [CrossRef]

93. Dong, H.; Jiang, S.; Fu, Y.; Luo, Y.; Gui, R.; Liu, J. Upregulation of lncRNA NR_046683 Serves as a Prognostic Biomarker and Potential Drug Target for Multiple Myeloma. Front. Pharmacol. 2019, 10, 45. [CrossRef]

94. Liu, D.; Wang, J.; Liu, M. Long noncoding RNA TUG1 promotes proliferation and inhibits apoptosis in multiple myeloma by inhibiting miR-29b-3p. Biosci. Rep. 2019, 39. [CrossRef] 
95. Yang, Y.; Chen, L. Downregulation of lncRNA UCA1 facilitates apoptosis and reduces proliferation in multiple myeloma via regulation of the miR-1271-5p/HGF axis. J. Chin. Med. Assoc. 2019, 82, 699-709. [CrossRef]

96. Li, J.-L.; Liu, X.-L.; Guo, S.-F.; Yang, Y.; Zhu, Y.-L.; Li, J.-Z. Long noncoding RNA UCA1 regulates proliferation and apoptosis in multiple myeloma by targeting miR-331-3p/IL6R axis for the activation of JAK2/STAT3 pathway. Eur. Rev. Med. Pharmacol. Sci. 2019, 23, 9238-9250. [CrossRef]

97. Pu, J.; Huang, H.; Su, J.; Yuan, J.; Cong, H.; Wang, X.; Ju, S. Decreased expression of long noncoding RNA XLOC_013703 promotes cell growth via NF-kB pathway in multiple myeloma. IUBMB Life 2019, 71, 1240-1251. [CrossRef]

98. Iyer, M.K.; Niknafs, Y.S.; Malik, R.; Singhal, U.; Sahu, A.; Hosono, Y.; Barrette, T.R.; Prensner, J.R.; Evans, J.R.; Zhao, S.; et al. The landscape of long noncoding RNAs in the human transcriptome. Nat. Genet. 2015, 47, 199-208. [CrossRef]

99. Gupta, S.C.; Tripathi, Y.N. Potential of long non-coding RNAs in cancer patients: From biomarkers to therapeutic targets. Int. J. Cancer 2017, 140, 1955-1967. [CrossRef]

100. Yang, X.; Yang, B. lncRNA PDIA3P regulates cell proliferation and invasion in non-small cell lung cancer. Exp. Ther. Med. 2019, 18, 3184-3190. [CrossRef]

101. Zhou, C.-C.; Yang, F.; Yuan, S.-X.; Ma, J.-Z.; Liu, F.; Yuan, J.-H.; Bi, F.-R.; Lin, K.-Y.; Yin, J.-H.; Cao, G.-W.; et al. Systemic genome screening identifies the outcome associated focal loss of long noncoding RNA PRAL in hepatocellular carcinoma. Hepatology 2016, 63, 850-863. [CrossRef]

102. Su, P.; Wang, F.; Qi, B.; Wang, T.; Zhang, S. P53 Regulation-Association Long Non-Coding RNA (LncRNA PRAL) Inhibits Cell Proliferation by Regulation of P53 in Human Lung Cancer. Med. Sci. Monit. 2017, 23, 1751-1758. [CrossRef]

103. Sun, Y.; Ma, L. New Insights into Long Non-Coding RNA MALAT1 in Cancer and Metastasis. Cancers 2019, 11, 216. [CrossRef]

104. Han, Y.; Wu, Z.; Wu, T.; Huang, Y.; Cheng, Z.; Li, X.; Sun, T.; Xie, X.; Zhou, Y.; Du, Z. Tumor-suppressive function of long noncoding RNA MALAT1 in glioma cells by downregulation of MMP2 and inactivation of ERK/MAPK signaling. Cell Death Dis. 2016, 7, e2123. [CrossRef]

105. Yu, X.; Li, Z.; Zheng, H.; Chan, M.T.V.; Wu, W.K.K. NEAT1: A novel cancer-related long non-coding RNA. Cell Prolif. 2017, 50, e12329. [CrossRef]

106. Xiong, D.-D.; Li, Z.-Y.; Liang, L.; He, R.-Q.; Ma, F.-C.; Luo, D.-Z.; Hu, X.-H.; Chen, G. The LncRNA NEAT1 Accelerates Lung Adenocarcinoma Deterioration and Binds to Mir-193a-3p as a Competitive Endogenous RNA. Cell. Physiol. Biochem. 2018, 48, 905-918. [CrossRef]

107. Gao, D.; Lv, A.-E.; Li, H.-P.; Han, D.-H.; Zhang, Y.-P. LncRNA MALAT-1 Elevates HMGB1 to Promote Autophagy Resulting in Inhibition of Tumor Cell Apoptosis in Multiple Myeloma. J. Cell. Biochem. 2017, 118, 3341-3348. [CrossRef]

108. Samur, M.K.; Minvielle, S.; Gulla, A.; Fulciniti, M.; Cleynen, A.; Samur, A.A.; Szalat, R.; Shammas, M.; Magrangeas, F.; Tai, Y.-T.; et al. Long intergenic non-coding RNAs have an independent impact on survival in multiple myeloma. Leukemia 2018, 32, 2626-2635. [CrossRef]

109. Schmitt, A.M.; Chang, H.Y. Long Noncoding RNAs in Cancer Pathways. Cancer Cell 2016, 29, 452-463. [CrossRef]

110. Ling, H.; Fabbri, M.; Calin, G.A. MicroRNAs and other non-coding RNAs as targets for anticancer drug development. Nat. Rev. Drug Discov. 2013, 12, 847-865. [CrossRef]

111. Arman, K.; Möröy, T. Crosstalk Between MYC and lncRNAs in Hematological Malignancies. Front. Oncol. 2020, 10, 579940. [CrossRef] [PubMed]

112. Jia, Q.; Chen, S.; Tan, Y.; Li, Y.; Tang, F. Oncogenic super-enhancer formation in tumorigenesis and its molecular mechanisms. Exp. Mol. Med. 2020, 52, 713-723. [CrossRef] [PubMed]

113. Lovén, J.; Hoke, H.A.; Lin, C.Y.; Lau, A.; Orlando, D.A.; Vakoc, C.R.; Bradner, J.E.; Lee, T.I.; Young, R.A. Selective Inhibition of Tumor Oncogenes by Disruption of Super-Enhancers. Cell 2013, 153, 320-334. [CrossRef] [PubMed]

114. Zhang, X.; Pang, P.; Jiang, M.; Cao, Q.; Li, H.; Xu, Y.; Li, Y.; Chen, X.; Han, J. eRNAs and Superenhancer IncRNAs Are Functional in Human Prostate Cancer. Dis. Markers 2020, 2020, 8847986. [CrossRef] [PubMed]

115. Li, G.; Zheng, Y.-H.; Xu, L.; Feng, J.; Tang, H.-L.; Luo, C.; Song, Y.-P.; Chen, X.-Q. BRD4 inhibitor nitroxoline enhances the sensitivity of multiple myeloma cells to bortezomib in vitro and in vivo by promoting mitochondrial pathway-mediated cell apoptosis. Ther. Adv. Hematol. 2020, 11, 2040620720932686. [CrossRef] [PubMed]

116. Díaz, T.; Rodríguez, V.; Lozano, E.; Mena, M.-P.; Calderón, M.; Rosiñol, L.; Martínez, A.; Tovar, N.; Pérez-Galán, P.; Bladé, J.; et al. The BET bromodomain inhibitor CPI203 improves lenalidomide and dexamethasone activity in in vitro and in vivo models of multiple myeloma by blockade of Ikaros and MYC signaling. Haematologica 2017, 102, 1776-1784. [CrossRef]

117. Stubbs, M.C.; Burn, T.C.; Sparks, R.; Maduskuie, T.; Diamond, S.; Rupar, M.; Wen, X.; Volgina, A.; Zolotarjova, N.; Waeltz, P.; et al. The Novel Bromodomain and Extraterminal Domain Inhibitor INCB054329 Induces Vulnerabilities in Myeloma Cells That Inform Rational Combination Strategies. Clin. Cancer Res. 2018, 25, 300-311. [CrossRef]

118. Delmore, J.E.; Issa, G.C.; Lemieux, M.E.; Rahl, P.B.; Shi, J.; Jacobs, H.M.; Kastritis, E.; Gilpatrick, T.; Paranal, R.M.; Qi, J.; et al. BET Bromodomain Inhibition as a Therapeutic Strategy to Target c-Myc. Cell 2011, 146, 904-917. [CrossRef]

119. Chaidos, A.; Caputo, V.; Gouvedenou, K.; Liu, B.; Marigo, I.; Chaudhry, M.S.; Rotolo, A.; Tough, D.F.; Smithers, N.N.; Bassil, A.K.; et al. Potent antimyeloma activity of the novel bromodomain inhibitors I-BET151 and I-BET762. Blood 2014, 123, 697-705. [CrossRef] 
120. Abruzzese, M.P.; Bilotta, M.T.; Fionda, C.; Zingoni, A.; Soriani, A.; Petrucci, M.T.; Ricciardi, M.R.; Molfetta, R.; Paolini, R.; Santoni, A.; et al. The homeobox transcription factor MEIS2 is a regulator of cancer cell survival and IMiDs activity in Multiple Myeloma: Modulation by Bromodomain and Extra-Terminal (BET) protein inhibitors. Cell Death Dis. 2019, 10, 324. [CrossRef]

121. Kole, R.; Krainer, A.R.; Altman, S. RNA therapeutics: Beyond RNA interference and antisense oligonucleotides. Nat. Rev. Drug Discov. 2012, 11, 125-140. [CrossRef]

122. Roberts, T.C.; Langer, R.; Wood, M.J.A. Advances in oligonucleotide drug delivery. Nat. Rev. Drug Discov. 2020, 19, 673-694. [CrossRef]

123. Gilboa-Geffen, A.; Hamar, P.; Le, M.T.; Wheeler, L.A.; Trifonova, R.; Petrocca, F.; Wittrup, A.; Lieberman, J. Gene Knockdown by EpCAM Aptamer-siRNA Chimeras Suppresses Epithelial Breast Cancers and Their Tumor-Initiating Cells. Mol. Cancer Ther. 2015, 14, 2279-2291. [CrossRef]

124. Wen, J.; Tao, W.; Hao, S.; Iyer, S.P.; Zu, Y. A unique aptamer-drug conjugate for targeted therapy of multiple myeloma. Leukemia 2015, 30, 987-991. [CrossRef]

125. Yoon, S.; Wu, X.; Armstrong, B.; Habib, N.; Rossi, J.J. An RNA Aptamer Targeting the Receptor Tyrosine Kinase PDGFR $\alpha$ Induces Anti-tumor Effects through STAT3 and p53 in Glioblastoma. Mol. Ther. Nucleic Acids 2019, 14, 131-141. [CrossRef]

126. Zhou, J.; Rossi, J. Aptamers as targeted therapeutics: Current potential and challenges. Nat. Rev. Drug Discov. 2017, 16, 181-202. [CrossRef] 